\title{
Role of post-settlement mortality and 'supply-side' ecology in setting patterns of intertidal distribution in the chthamalid barnacles Chthamalus montagui and $C$. stellatus
}

\author{
J. Delany ${ }^{1, *}$, A. A. Myers ${ }^{2}$, D. McGrath ${ }^{3}$, R. M. O'Riordan ${ }^{2,4}$, A. M. Power $^{2}$ \\ ${ }^{1}$ Dove Marine Laboratory, Department of Marine Sciences and Coastal Management, \\ University of Newcastle upon Tyne NE30 4PZ, United Kingdom \\ ${ }^{2}$ Department of Zoology and Animal Ecology, University College Cork, Lee Maltings, Prospect Row, Cork, Ireland \\ ${ }^{3}$ Department of Life Sciences, Galway-Mayo Institute of Technology, Galway, Ireland \\ ${ }^{4}$ Department of Biological Sciences, National University of Singapore, 117543 Singapore
}

\begin{abstract}
The chthamalid barnacles Chthamalus montagui and C. stellatus occupy distinctive distributional patterns on European rocky shores. To explore whether these patterns are determined primarily by larval settlement or by post-settlement mortality, we examined the abundance of each species from cyprid attachment through successive stages in its intertidal life history and thus attempted to determine the critical stage for the establishment of adult patterns of dominance. Sampling was carried out on 4 shores in Cork, SW Ireland. On 2 of the shores, sampling sites were in zones in the upper shore dominated by $C$. montagui, and on the other 2 shores, sites were in zones in the midshore dominated by $C$. stellatus. The patterns of cyprid settlement and recruitment of early metamorphs in these zones did not reflect that of adult abundances. Patterns of mortality of the 2 species were determined from photographs. Mortality of recruits between 6 and 12 mo after settlement differed between the 2 zones. Mortality of $C$. montagui was higher than that of $C$. stellatus in the midshore zone, while the reverse trend was observed in the upper C. montagui-dominated zone, with C. stellatus recruits suffering higher rates of mortality than those of C. montagui. Post-settlement mortality, rather than larval supply, was therefore deemed to be the more significant factor in determining the characteristic patterns of these chthamalid species on SW Ireland shores.
\end{abstract}

KEY WORDS: Larval supply · Post-settlement mortality $\cdot$ Chthamalus montagui $\cdot$ C. stellatus Resale or republication not permitted without written consent of the publisher

\section{INTRODUCTION}

Understanding the factors controlling the abundance and distribution of organisms is a central theme in ecology. Community structure in intertidal rocky shores can be affected by temporal and spatial variations in larval supply (Underwood \& Denley 1984, Gaines et al. 1985, Judge et al. 1988). In barnacles, variation in the abundance of adults has been attributed to variations in reproductive output, to fluctuations in nearshore current patterns or wind directions, or to differences in coastal topography and substrate types (e.g. Knight-Jones \& Stevenson 1950, Barnes 1956, 1962, Connell 1961a, De Wolf 1973, Hawkins \& Hartnoll 1982, Kendall et al. 1982, Gaines et al. 1985, Sutherland 1990, Wethey 1985). While these factors are important, some studies attribute apparent spatial variation in recruitment to disproportionate weighting of larval supply, with no examination of events at settlement and early mortality patterns (e.g. Dye 1993, Noda \& Nakao 1996). Attempts to understand how adult distributions are established and maintained from the abundance of recruits several months after settlement is unlikely to be successful. High rates of 
early post-settlement mortality appear to be widespread among marine invertebrate species (for reviews see Gosselin \& Qian 1997, Hunt \& Scheibling 1997), and this early post-settlement mortality can exhibit high temporal and spatial variability. It is only in recent years that quantitative evidence has emerged on the conditions under which larval supply is comparatively important (Connell 1985, Gaines \& Roughgarden 1985, Holm 1990, Hughes 1990, Menge 1991, 1992). The relative importance of larval supply has been shown to vary within a species both temporally and spatially (Gaines \& Roughgarden 1985, Minchinton \& Scheibling 1991, Carroll 1996), and also between communities (Menge 1991). While valuable information can result from a comparison of the distribution of different cohorts at a given time (e.g. Raimondi 1988), temporal variation in mortality may confound patterns of abundance of cohorts. The role of larval supply has also been investigated by comparing the distribution at settlement with that of adults (Moyse \& Knight-Jones 1967, Grosberg 1982, Raimondi 1988, Coates \& McKillup 1995). Evaluation of any factor is incomplete unless its contribution to adult patterns relative to other factors is assessed, and the relative importance of the various processes in regulating the dynamics of adult populations are best addressed in studies which follow individuals from settlement to adulthood (Raimondi 1990, Minchinton \& Scheibling 1991, Carroll 1996).

It is not known whether the distinctive adult distribution patterns of the chthamalid barnacles Chthamalus montagui Southward and C. stellatus (Poli) on European rocky shores are determined primarily by larval settlement or by post-settlement processes. In SW Ireland, C. montagui increases in abundance in sheltered locations and towards the high-water neap-tide level on all shores where chthamalid species occur. C. stellatus may be found on all such shores and, with increasing exposure, extends upwards into the C. montagui zone. Since their recognition as separate species (Southward 1976), there have been a number of studies on the recruitment (Bennell 1981, Cross \& Southgate 1983, Miyares 1986, Kendall \& Bedford 1987, Burrows 1988, Healy \& McGrath 1998, B. Healy unpubl., A. A. Myers et al. unpubl.) and mortality (Burrows 1988, Shkedy et al. 1995) of these 2 species. Failure to identify the cyprids has, however, precluded any comparative study of their vertical distribution at settlement.

This study set out to determine at what stage during their shore life the composition of the adult population of these 2 species is established. This was achieved by examining the relative abundance of the species at cyprid attachment through successive stages to 18 mo of age. Mortality patterns were investigated by photographic monitoring of individuals older than 6 mo.

\section{MATERIALS AND METHODS}

Sampling was carried out on 4 shores within $15 \mathrm{~km}$ of each other in County Cork, SW Ireland. The shores were exposed to moderately exposed ( 2 to 4 on the Ballantine scale of exposure). Two chthamalid zones were sampled. On all shores, the midshore population of Chthamalus spp. was dominated by C. stellatus, which comprised 60 to $100 \%$ of the adult chthamalids. Sampling was carried out in this zone on 2 of the 4 shores. On the other 2 shores, the upper-shore zone was sampled, where C. montagui comprised 80 to $100 \%$ of the adult Chthamalus population. Densities of adult chthamalids in each of the zones were calculated from counts of barnacles in 10 replicate quadrates $\left(10 \times 10 \mathrm{~cm}^{2}\right)$.

All shores were sampled monthly, within $5 \mathrm{~d}$ either side of the lowest spring tide, from July 1996 to June 1997. Collections were made from adult populations to identify recruitment patterns in natural populations as opposed to those on plates or from cleared areas. All cyprids and metamorphs were collected with fine forceps from each of 6 random replicate $10 \times 10 \mathrm{~cm}^{2}$ quadrats, at each of 3 sites (per zone) that were haphazardly selected each month. At peak settlement, smaller quadrats $\left(5 \times 5 \mathrm{~cm}^{2}\right)$ were used. Field magnification lenses $(\times 8)$ reduced the risk of any individual being overlooked. Samples were transported to the laboratory in vials of $70 \%$ ethanol. Under light microscope magnification in the laboratory, cyprids were identified on the basis of carapace length (O'Riordan et al. 1999, Power et al. 1999a), and early metamorphs on the basis of morphological criteria (Burrows 1988). Barnacles were determined to be $<1$ mo old based on the criteria of size, colour and degree of calcification (Power et al. 1999b).

Mortality patterns in older recruits were monitored photographically. Within each of the zones, 3 fixed quadrats of area $50 \times 20 \mathrm{~cm}^{2}$ were established. For accurate relocation of the sites, brass climbing anchors (Petzl, cheville autoforeuse P12) were drilled into the rock, to which a graduated aluminium frame could be bolted at each visit. The frame was subdivided into $5 \times 5 \mathrm{~cm}^{2}$ squares, 6 of which were randomly selected and photographed in January and July 1997 using a mediumformat camera. A new series of sites was established and photographed in July 1997 and again in January 1998. Images were digitized and analysed using imageanalysis software (PC Image). The software enabled the presence or absence, opercular size and location of individuals to be recorded, but identification to species level and accurate aging was beyond the scope of the technology used and were recorded manually. Counts were made of chthamalids of approximately 6 to 12 mo, and 12 to 18 mo of age in the first and second series of photographs respectively. It was therefore possible to 
follow individual juvenile barnacles over the 6 mo periods, within each pair of photographs, and to determine the patterns of mortality. In both the shore collections and the photographs, 3 of the 6 replicates in each case were randomly selected for statistical analysis of counts of Chthamalus montagui, and the other 3 were used for counts of C. stellatus.

A 2-factor ANOVA was carried out on the adult densities to determine whether the density of the 2 species differed within each zone, and whether the density of each species differed between zones. A 1-factor ANOVA was carried out to determine whether total chthamalid density varied between the 2 zone types examined.

To examine the relative cyprid input of each species to each zone during the main settlement season, analysis was carried out on the total cyprid abundance using a 4 -factor ANOVA with zone (upper- and midshore) and species (Chthamalus montagui and C. stellatus) as fixed factors and shore as a random factor (2 levels) nested in zone. Site was a random factor nested within the zone $\times$ shore interaction. As 4 sampling occasions were considered for this analysis (the main settlement season), and as each of the 3 sites per shore were haphazardly selected each month, there were in effect 12 levels for the factor 'site'. A similar analysis was carried out on the densities of newly recruited metamorphs (at the appropriate maximum age of $1 \mathrm{mo}$ ) over the same period. Cochran's C-test (Winer et al. 1971, Underwood 1981) was used before each analysis to check whether variances were homogenous. When necessary, densities were $\ln (x+0.1)$-transformed. Student's $t$-tests were used to compare the total abundance of cyprids of each species between the 2 zone types. Analysis of the mortality data was carried out using a 4 -factor analysis of variance with zone (fixed), shore (random and nested in zone), site (random and nested within the zone $\times$ shore interaction) and species (fixed, orthogonal). The 2 periods (January to July 1997 and July 1997 to January 1998) were analysed separately. On one shore (mid zone), not all recruits could be identified from photographs at the 6 mo old recruit stage (January 1997); percentage mortality was therefore only estimated from identifiable individuals; this may have introduced a small error.

\section{RESULTS}

The densities of adult chthamalids within the zone sampled on each shore are shown in Table 1. A significant zone $x$ species interaction was found in the analysis of adult chthamalid densities (2-way ANOVA: $\mathrm{df}=1, F=129.85, \mathrm{p}<0.001)$. Tukey multiple comparisons tests revealed that the density of each species varied significantly between zones, and that the density of the 2 species varied within both zones. The upper-shore zone was dominated by Chthamalus montagui and the midshore zone by C. stellatus. Total chthamalid density did not vary between zones (1-way ANOVA: $\mathrm{df}=1, F=1.59, \mathrm{p}=0.212$ ).

The main settlement season of both species was between early August and October, although cyprids were found sporadically throughout much of the year (Fig. 1). Analysis of cyprid densities and early metamorphs was therefore carried out on the combined data for these 4 months. Cyprids of Chthamalus stellatus were consistently more abundant than those of C. montagui in both zones sampled $(\mathrm{df}=1, F=3071.87$, $\mathrm{p}<0.001)$. There was no significant interaction of zone $\times$ species $(\mathrm{df}=1, F=6.11, \mathrm{p}=0.132)$, indicating that the proportion of $C$. montagui and C. stellatus cyprids did not vary significantly between the 2 zones. Student's $t$-tests showed significantly higher cyprid abundances of both $C$. montagui $(\mathrm{df}=142, t=3.13, \mathrm{p}<0.001)$ and C. stellatus ( $\mathrm{df}=142, t=2.73, \mathrm{p}=0.0072$ ) in the uppershore than in the midshore zones. During the main settlement season, there was also no significant interaction between zone and species in the abundance of metamorphs of an approximate maximum age of $1 \mathrm{mo}$ $(\mathrm{df}=1, F=0.07, \mathrm{p}=0.8109)$.

There was, however, a significant interaction between zone and species (Table 2), for the percentage mortality of recruits between 6 and 12 mo. This implies that the 2 species exhibited different rates of mortality in the different zones. Student-Newman-Keuls tests within the zone $\times$ species interaction indicate that mortality of Chthamalus stellatus was significantly higher than that of C. montagui in the upper-shore zone, while the mortality of $C$. montagui in the midshore zone was higher than that of $C$. stellatus. Within each species, multiple comparisons showed that mortality differed between the zones. C. montagui suffered

Table 1. Chthamalus montagui and C. stellatus. Densities and relative proportions of adults in each zone sampled (sampling was on 4 different shores in SW Ireland). Values are mean per $10 \times 10 \mathrm{~cm}^{2} \pm \mathrm{SD} ; \mathrm{n}=10$

\begin{tabular}{|lccc|}
\hline Zone & C. montagui & C. stellatus & $\begin{array}{c}\text { C. montagui as \% of } \\
\text { total chthamalids }\end{array}$ \\
\hline Upper-shore & & & \\
Shore 1 & $501.0 \pm 86.6$ & $9.0 \pm 7.8$ & $98.2 \%$ \\
Shore 2 & $259.5 \pm 81.3$ & $39.5 \pm 15.3$ & $86.8 \%$ \\
Midshore & & & \\
Shore 3 & $131.0 \pm 10.3$ & $199.9 \pm 58.8$ & $39.6 \%$ \\
Shore 4 & $32.7 \pm 10.3$ & $299.7 \pm 90.2$ & $9.8 \%$ \\
\hline
\end{tabular}



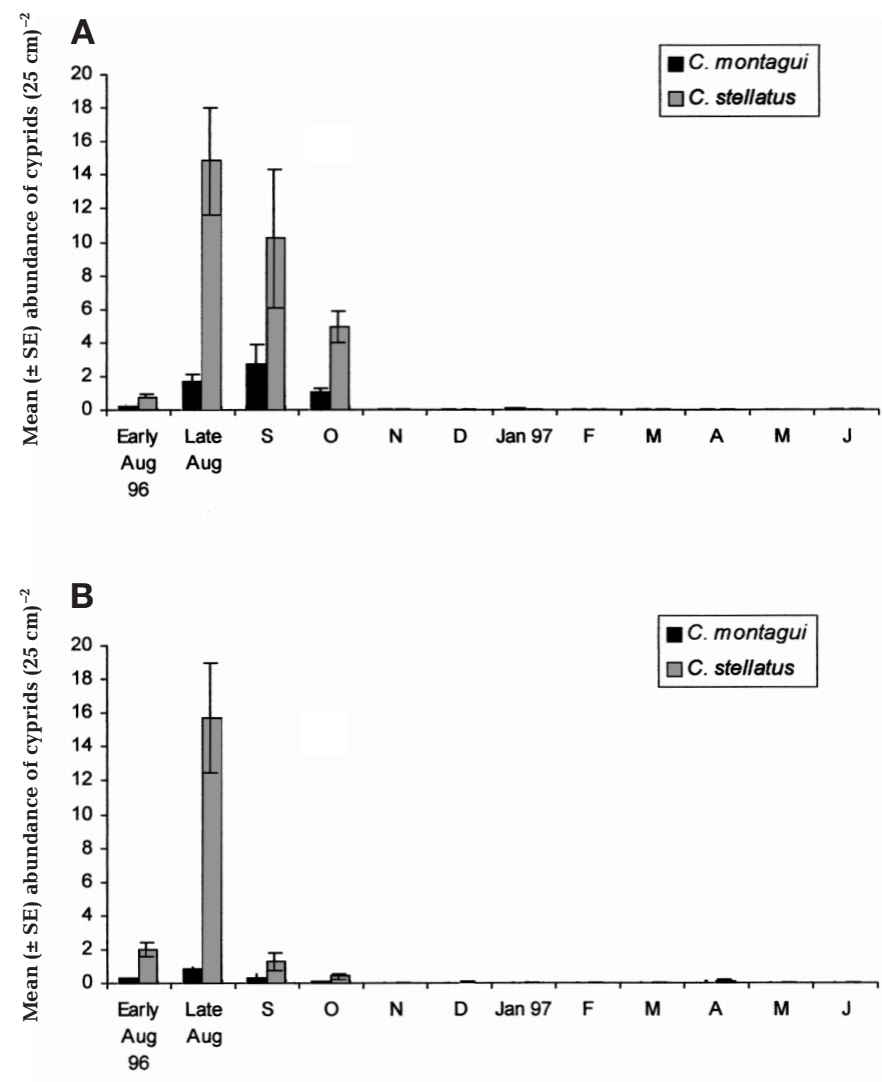

Fig. 1. Chthamalus montagui and C. stellatus. Abundance of cyprids in (A) upper-shore C. montagui-dominated zone, and (B) midshore C. stellatus-dominated zone

higher rates of mortality in the mid- compared to the upper-shore zone, while the reverse trend was observed for C. stellatus. There was no significant interaction between zone $\times$ species in the mortality of recruits between 12 and 18 mo (Table 2).
The initial proportions of the 2 species from the 1996 cohorts were broadly similar in the 2 zones, but they diverged gradually, to show a predominance of Chthamalus montagui recruits in the upper-shore zone 6 mo after initial settlement and a majority of C. stellatus in the 12 mo old juveniles in the midshore zone (Table 3).

\section{DISCUSSION}

The zone of highest density of attached cyprids of Chthamalus stellatus did not correspond with the zone of maximum adult density. A higher total abundance of C. stellatus cyprids was found in the upper-shore zone. Studies have identified larval supply as a primary factor in establishing distribution patterns in some species of barnacle, by showing that settlement is restricted to favourable sites (Moyse \& Knight-Jones 1967, Grosberg 1982, Raimondi 1988, Coates \& McKillup 1995). In species in which post-settlement mortality has been observed to 'trim' the newly settled population, larval settlement is also identified as an important process influencing adult distributions (Rice 1935, Hatton 1938, Connell 1961b, 1970, Denley \& Underwood 1979, Strathmann \& Branscomb 1979, Caffey 1985). In this study, larval settlement was not monitored above or below the adult vertical distribution limits of either species. Yet even at the fringes of the upper vertical distributional limit of C. stellatus, where abundances of adults are significantly lower, settlement is not reduced relative to the midshore zone. The abundance of Chthamalus montagui cyprids was also greater in the higher zone, in contrast to the findings of Kendall \& Bedford (1987) at Aberystwyth, Wales. Longer submersion times for mid- and lower zones have been cited as

Table 2. Chthamalus montagui and C. stellatus. Analysis of variance in mortality of juveniles between 6 and 12 mo and between 12 and 18 mo after settlement. Sampling was at 3 sites (Site, S) in 2 shore zones (Zone, Z) on 4 different shores (Shore, Sh). Sp: species. SNK: Student-Newman-Keuls

\begin{tabular}{|c|c|c|c|c|c|c|c|}
\hline \multirow{2}{*}{$\begin{array}{l}\text { Source of } \\
\text { variation }\end{array}$} & \multirow{2}{*}{$\mathrm{df}$} & \multicolumn{3}{|c|}{6 to $12 \mathrm{mo}$} & \multirow{2}{*}{ MS } & \multicolumn{2}{|c|}{ to $18 \mathrm{mo}$} \\
\hline & & MS & F & $\mathrm{p}$ & & $F$ & $\mathrm{p}$ \\
\hline Zone & 1 & 0.25 & 0.00 & 0.9565 & 0.87 & 0.00 & 0.9816 \\
\hline Shore (Z) & 2 & 67.10 & 0.33 & 0.7278 & 1286.36 & 3.62 & 0.0758 \\
\hline Site $(\mathrm{Sh} \times \mathrm{Z})$ & 8 & 202.89 & 0.71 & 0.6855 & 354.98 & 1.42 & 0.2142 \\
\hline Species & 1 & 578.96 & 3.76 & 0.1920 & 3433.10 & 1.83 & 0.3085 \\
\hline $\mathrm{Z} \times \mathrm{Sp}$ & 1 & 9813.10 & 63.74 & 0.0153 & 69.90 & 0.04 & 0.6847 \\
\hline $\operatorname{Sp} \times \operatorname{Sh}(Z)$ & 2 & 153.94 & 1.27 & 0.3310 & 1873.76 & 3.66 & 0.0742 \\
\hline $\mathrm{Sp} \times \operatorname{Si}(\mathrm{Sh} \times \mathrm{Z})$ & 8 & 120.96 & 0.42 & 0.9033 & 511.39 & 2.04 & 0.0613 \\
\hline Residual & 48 & 287.74 & & & 250.66 & & \\
\hline SNK multiple & \multirow{2}{*}{\multicolumn{2}{|c|}{ Z within levels of $\mathrm{Sp}$}} & \multirow{2}{*}{\multicolumn{2}{|c|}{$\begin{array}{l}\text { C. montagui } \\
\text { C. stellatus }\end{array}$}} & Upper < midshore zone & \multicolumn{2}{|c|}{ Significant } \\
\hline comparisons & & & & & Upper > midshore zone & \multirow{3}{*}{\multicolumn{2}{|c|}{$\begin{array}{l}\text { Significant } \\
\text { Significant }\end{array}$}} \\
\hline for 6 to $12 \mathrm{mo}$ & \multirow{2}{*}{\multicolumn{2}{|c|}{ Sp within levels of Z }} & Upper-shore zone & & C. montagui $<$ C. stellatus & & \\
\hline & & & Midshore zone & & C.montagui > C. stellatus & & \\
\hline
\end{tabular}


Table 3. Chthamalus montagui and C. stellatus. Densities (mean nos. $25 \mathrm{~cm}^{-2} \pm \mathrm{SD}$ ) and relative proportions of recruit and adult populations in upper-shore and midshore zones. For recruits up to $18 \mathrm{mo}, \mathrm{n}=18$; for adults, $\mathrm{n}=20$

\begin{tabular}{|c|c|c|c|c|c|c|c|c|}
\hline \multirow{2}{*}{$\begin{array}{l}\text { Zone } \\
\quad \text { Species }\end{array}$} & \multicolumn{4}{|c|}{ Settlement month } & \multirow[b]{2}{*}{$6 \mathrm{mo}$} & \multicolumn{2}{|c|}{ - Development stage } & \multirow[b]{2}{*}{ Adults } \\
\hline & Early August & Late August & September & October & & $12 \mathrm{mo}$ & $18 \mathrm{mo}$ & \\
\hline \multicolumn{9}{|l|}{ Upper-shore } \\
\hline C. montagui & $0.1 \pm 0.2$ & $1.7 \pm 1.7$ & $9.2 \pm 8.4$ & $11.4 \pm 13.7$ & $21.6 \pm 13.0$ & $16.0 \pm 9.4$ & $14.3 \pm 8.8$ & $85.0 \pm 35.6$ \\
\hline C. stellatus & $1.4 \pm 1.4$ & $4.4 \pm 3.4$ & $6.9 \pm 6.4$ & $9.0 \pm 9.3$ & $7.8 \pm 9.2$ & $2.5 \pm 2.6178$ & $3.2 \pm 6.0$ & $7.3 \pm 4.95$ \\
\hline $\begin{array}{l}\text { C. montagui } \\
\text { as \% of total } \\
\text { chthamalids }\end{array}$ & 7 & 28 & 57 & 56 & 73 & 86 & 82 & 92 \\
\hline \multicolumn{9}{|l|}{ Midshore } \\
\hline C. montagui & $0.1 \pm 0.2$ & $2.8 \pm 2.1$ & $22.7 \pm 6.3$ & $5.4 \pm 3.4$ & $16.6 \pm 13.8$ & $8.1 \pm 7.6$ & $5.2 \pm 2.7$ & $20.5 \pm 16.3$ \\
\hline C. stellatus & $0.9 \pm 1.2$ & $3.8 \pm 2.9$ & $29.9 \pm 26.8$ & $17.8 \pm 12.7$ & $23.8 \pm 20.0$ & $16.7 \pm 16.8$ & $12.2 \pm 11.7$ & $62.5 \pm 22.5$ \\
\hline $\begin{array}{l}\text { C. montagui } \\
\text { as \% of total } \\
\text { chthamalids }\end{array}$ & 10 & 42 & 43 & 23 & 41 & 33 & 30 & 25 \\
\hline
\end{tabular}

the cause for higher recruitment of barnacles at these levels (e.g. Minchinton \& Scheibling 1991). In the present study, it is therefore surprising that neither settlement nor recruitment of either species was reduced in the upper barnacle zone; however, Raimondi (1990) did observe similar patterns in the recruitment of C. anisopoma. C. stellatus contributed a significantly higher proportion of the total larval input than C. montagui. This was consistent in both zones, and was therefore independent of the relative proportion of the 2 species in the adult population. Considering the relative abundance of these 2 species, this evidence strongly suggests that the broadscale vertical zonation of chthamalid barnacles on shores in SW Ireland is not determined by patterns of larval settlement. Attributing these differences in cyprid density to shore height should, however, be done with some caution, since the zones (upper and mid) sampled were not on the same shores. This introduces a potential influence of differences between shores into the results. Sampling with more than 2 replicates would have increased the reliability of the data.

Metamorphs of both species were abundant throughout the settlement season (Fig. 2). The pattern of adult abundance in each type of zone was not reflected in the relative abundance of early metamorphs, as evidenced by the non-significant zone $\times$ species interaction term. This demonstrates that the proportions of the 2 species did not vary between zones at this stage. As with the cyprids, difficulties in separating the species at the very young metamorph stage have hindered earlier comparisons of the vertical recruitment patterns where they co-exist. Where one of the species is regionally absent or rare, conclusions about settlement and recruitment patterns of the second species have been confidently drawn (Kendall \& Bedford 1987, Benedetti-Cecchi et al. 2000). In contrast to the results presented here, Burrows (1988) found that the proportions of the 2 species varied between different shore heights, and that although early recruits of Chthamalus montagui could be found throughout the intertidal, similar stages of $C$. stellatus were restricted to the lower shore levels. One explanation for this inconsistency could be that shores along the south coast of Ireland experience greater wave exposure that the shores sampled by Burrows (Plymouth, UK), with the result that only on Irish shores were the early metamorphs of C. stellatus capable of colonising the upper barnacle zone.

It is evident from Figs. 1 \& 2 that there is much less disparity between the frequencies of early recruits of the 2 species within a zone than for the frequencies of the cyprid stage. Evidence from further work (Power et al. 1999b, J. Delany et al. unpubl.) suggests that Chthamalus montagui may metamorphose at a faster rate than C. stellatus and/or that the former species has a higher metamorphic success, and therefore would be recorded less frequently as a cypris stage. The difference in numbers between cyprids and early recruits for consecutive sampling periods supports this. For example, in the midshore zone, an average of $0.8 \mathrm{C}$. montagui cyprids $25 \mathrm{~cm}^{-2}$ were found in late August, yet an average of 19.9 metamorphs $25 \mathrm{~cm}^{-2}$ for this species was found in September (Figs. 1 \& 2). For C. stellatus, these figures are 15.7 and 27.7 respectively in this zone. It is possible that differential mortality between sampling periods in the current study may have already altered the relative abundances of the 2 species and affected our interpretations of settlement patterns. Patterns of mortality rates over the early months of shore life vary between barnacle species (Connell 1961b, Gaines \& Roughgarden 1985, Raimondi 1990, Sutherland 1990, Young 1991, Gosselin \& Qian 1996). Without quantification of mortality from the onset of 

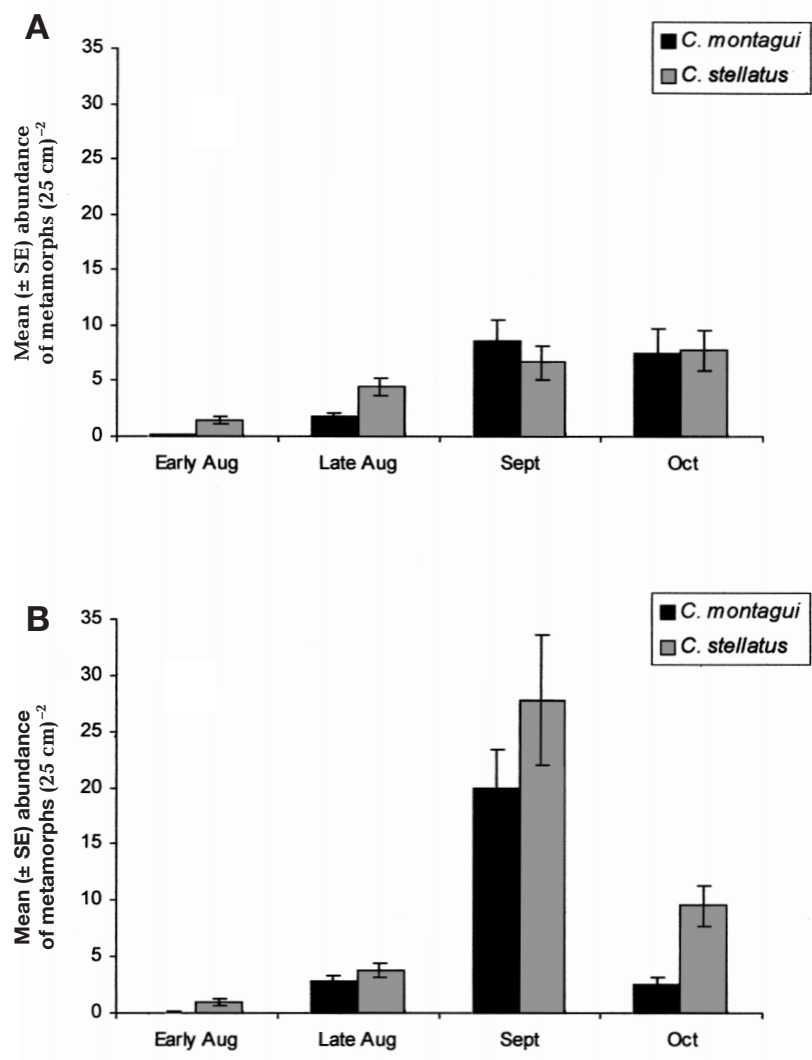

Fig. 2. Chthamalus montagui and C. stellatus. Abundance of metamorphosis in (A) upper-shore C. montagui-dominated zone, and (B) midshore C. stellatus-dominated zone

shore life, attempts to estimate the role of larval supply to subsequent populations may be impeded by underestimates of settlement (Gosselin \& Qian 1997). Regardless of these problematical issues, it is clear that neither at the attached cyprid stage nor at the early recruit stage was the pattern of adult dominance established in either zone.

While the data demonstrate no connection between the relative settlement patterns and the patterns of adult abundance of the 2 species, there is evidence that differential mortality in each zone is of major importance in maintaining the characteristic patterns of Chthamalus spp. distribution on shores in SW Ireland. Mortality of C. montagui between 6 and 12 mo was greater in the midshore zone than at higher levels, while the reverse trend was observed for C. stellatus. This is in agreement with the findings of Burrows (1988) with estimates determined on cleared squares on a single shore. Desiccation is a well-documented cause of mortality in upper shore levels (Connell 1961a, Foster 1971, Dungan 1985, Hoffman 1989, Minchinton \& Scheibling 1991). A greater tolerance of desiccation would explain why $C$. montagui has higher survival rates than $C$. stellatus in the upper-shore zone. It would not, however, explain the lower survival of C. montagui in the midshore zone at Cork and Plymouth. Investigations by Burrows (1988) into the relative mortality rates under different immersion regimes revealed that while $C$. stellatus displayed lower survival rates over longer exposure times, C. montagui actually fared worse when submitted to long periods of submersion corresponding to lower shore levels. Further evidence to support the high survival rate of C. montagui in drier areas is provided by a study by Power at al. (2001). Kendall \& Bedford (1987), however, found no such differences between shore heights in mortality rates of much younger individuals (up to $11 \mathrm{~d}$ old) of C. montagui. It is feasible to assume that any influence of submersion times may not be detected at such an early stage. Alternatively, since sampling was carried out above the Semibalanus spp. zone, it is possible that their population may not have experienced sufficiently long submersion periods to affect mortality rates unduly (no tidal heights were given). Where higher mortality of $C$. stellatus has been reported at lower levels (Shkedy et al. 1995, Benedetti-Cecchi et al. 2000), overgrowth by algae was determined to be the cause. The changing ratio of the 2 species over time (Table 3) suggests that the vertical patterns of mortality determined from the photographic study are also likely to affect recruits younger that 6 mo old. Establishment of dominance by each species is thus a gradual process, with differential mortality trimming the distributions in each zone.

Acknowledgements. We gratefully acknowledge the European Community for funding this study under MAST-3 Programme, Contract No. MAST-CT95-0012.

\section{LITERATURE CITED}

Barnes H (1956) Balanus balanoides L. in the Firth of Clyde: the development and annual variation in the larval population and the causative factors. J Anim Ecol 25:72-84

Barnes H (1962) Notes on the variations in the release of nauplii of Balanus balanoides with special reference to the spring diatom outburst. Crustaceana 4:118-122

Benedetti-Cecchi L, Acunto S, Bulleri F, Cinelli F (2000) Population ecology of the barnacle Chthamalus stellatus (Poli) in the northwest Mediterranean. Mar Ecol Prog Ser 198: $157-170$

Bennell SH (1981) Some observations on the littoral barnacle populations of North Wales. Mar Environ Res 5:227-240

Burrows MT (1988) The comparative biology of Chthamalus stellatus (Poli) and Chthamalus montagui Southward. PhD thesis, University of Manchester

Caffey HM (1985) Spatial and temporal variation in settlement and recruitment of intertidal barnacles. Ecol Monogr 55:313-332

Carroll ML (1996) Barnacle population dynamics and recruitment regulation in south-central Alaska. J Exp Mar Biol Ecol 199:285-302

Coates M, McKillup SC (1995) Role of recruitment and growth 
in determining the upper limit of distribution of the intertidal barnacle Hexaminius popeiana. Mar Freshw Res 46: 1065-1070

Connell JH (1961a) Effects of competition, predation by Thais lapillus and other factors on natural populations of the barnacle Balanus balanoides. Ecol Monogr 31:313-332

Connell JH (1961b) The influence of interspecific competition and other factors on the distribution of the barnacle Chthamalus stellatus. Ecology 42:710-723

Connell JH (1970) A predator-prey system in the marine intertidal region. I. Balanus glandula and several species of Thais. Ecol Monogr 40:49-78

Connell JH (1985) The consequences of variation in settlement vs. post-settlement mortality in rocky intertidal communities. J Exp Mar Biol Ecol 93:11-46

Cross TF, Southgate T (1983) An approach to ecological monitoring in the rocky intertidal: a survey of Bantry Bay and Dunmanus Bay, Ireland. Mar Environ Res 8:149-163

Denley EJ, Underwood AJ (1979) Experiments on factors influencing settlement, survival and growth of two species of barnacles in New South Wales. J Exp Mar Biol Ecol 36: 269-293

De Wolf P (1973) Ecological observations on the mechanisms of dispersal of barnacle larvae during planktonic life and settling. Neth J Sea Res 6:1-129

Dungan ML (1985) Competition, and the morphology, ecology, and evolution of acorn barnacles: an experimental test. Paleobiology 11:165-173

Dye AH (1993) Aspects of the population dynamics of Chthamalus dentatus (Crustacea: Cirripedia) on the Transkei coast of southern Africa. S Afr J Mar Sci 13:25-32

Foster BA (1971) Desiccation as a factor in the intertidal zonation of barnacles. Mar Biol 8:12-29

Gaines S, Roughgarden J (1985) Larval settlement rate: a leading determinant of structure in an ecological community of the marine intertidal zone. Proc Natl Acad Sci USA 82:3703-3711

Gaines S, Brown S, Roughgarden J (1985) Spatial variation in larval concentrations as a cause of spatial variation in settlement for the barnacle Balanus glandula. Oecologia 67:267-272

Gosselin LA, Qian P (1996) Early post-settlement mortality of an intertidal barnacle: a critical period for survival. Mar Ecol Prog Ser 135:69-75

Gosselin LA, Qian P (1997) Juvenile mortality in benthic marine invertebrates. Mar Ecol Prog Ser 146:265-282

Grosberg RK (1982) Intertidal zonation of barnacles: the influence of planktonic zonation of larvae on vertical distribution of adults. Ecology 63:894-899

Hatton H (1938) Essais de bionomie explicative sur quelques especes intercotidales d'algues et de animaux. Ann Insti Océanogr 17:241-348

Hawkins SJ, Hartnoll RG (1982) Settlement patterns of Semibalanus balanoides (L.) in the Isle of Man (1977-1981). J Exp Mar Biol Ecol 62:271-283

Healy B, McGrath D (1998) Marine fauna of County Wexford, Ireland: the fauna of rocky shores and sandy beaches. Ir Fish Investig (New Ser) 2:1-71

Hoffman DL (1989) Settlement and recruitment patterns of a pedunculate barnacle, Pollicipes polymerus Sowerby, off La Jolla, California. J Exp Mar Biol Ecol 125:83-98

Holm ER (1990) Effects of density-dependent mortality on the relationship between recruitment and larval settlement. Mar Ecol Prog Ser 60:141-146

Hughes TP (1990) Recruitment limitation, mortality and population regulation in open systems: a case study. Ecology 71:12-20
Hunt L, Scheibling RE (1997) Role of early post-settlement mortality in recruitment of benthic marine invertebrates. Mar Ecol Prog Ser 155:269-301

Judge ML, Quinn JF, Wolin CL (1988) Variability in recruitment of Balanus glandula (Darwin, 1954) along the central California coast. J Exp Mar Biol Ecol 119:235-251

Kendall MA, Bedford ML (1987) Reproduction and recruitment of the barnacle Chthamalus montagui at Aberystwyth (mid-Wales). Mar Ecol Prog Ser 38:305-308

Kendall MA, Bowman RS, Williamson P, Lewis JR (1982) Settlement patterns density and stability in the barnacle Balanus balanoides. Neth J Sea Res 16:119-126

Knight-Jones EW, Stevenson JP (1950) Gregariousness during settlement in the barnacle Elminius modestus Darwin. J Mar Biol Assoc UK 29:291-297

Menge BA (1991) Relative importance of recruitment and other causes of variation in rocky intertidal community structure. J Exp Mar Biol Ecol 146:69-100

Menge BA (1992) Community regulation: under what conditions are bottom-up factors important on rocky shores? Ecology 73:755-765

Minchinton TE, Scheibling RE (1991) The influence of larval supply and settlement on the population structure of barnacles. Ecology 72:1876-1879

Miyares MP (1986) Estudio del horizonte de ChthamalusPatella en el litoral Asturiano. PhD thesis, University of Oviedo

Moyse J, Knight-Jones EW (1967) Biology of cirripede larvae. Proc Symp Crustacea, Ernakulam, 1965, Part 1. Marine Biological Society of India, Bangalore Press, Bengal, p 595-611

Noda T, Nakao S (1996) Multi-scale spatial pattern of recruitment in the barnacles Semibalanus cariosus at fishing ports on the Kameda peninsula, southern Hokkaido, Japan. Hydrobiologia 324:125-130

O'Riordan RM, Myers AA, McGrath D, Delany J, Power A (1999) The sizes at settlement in natural populations of the cyprids of Chthamalus montagui and C. stellatus. J Mar Biol Assoc UK 79:365-366

Power AM, Piyapattanakorn S, O'Riordan RM, Iyengar A and 5 others (1999a) Verification of cyprid size as a tool in the identification of two European species of Chthamalus barnacle using mtDNA RFLP analysis. Mar Ecol Prog Ser 191:251-256

Power AM, Delany J, Myers AA, O'Riordan RM, McGrath D (1999b) Prolonged settlement and prediction of recruitment in two sympatric intertidal Chthamalus species from south-west Ireland. J Mar Biol Assoc UK 79:941-943

Power AM, Myers AA, O'Riordan RM, McGrath D, Delany J (2001) An investigation into rock surface wetness as a parameter contributing to the distribution of the intertidal barnacles Chthamalus stellatus and Chthamalus montagui. Estuar Coast Shelf Sci 52:349-356

Raimondi PT (1988) Settlement cues and determination of the vertical limit of an intertidal barnacle. Ecology 69:400-407

Raimondi PT (1990) Patterns, mechanisms, consequences of variability in settlement and recruitment of an intertidal barnacle. Ecol Monogr 60:282-309

Rice LA (1935) Factors controlling arrangement of barnacle species in tidal communities. Ecol Monogr 5:293-304

Shkedy Y, Safriel UN, Keasar T (1995) Life-history of Balanus amphitrite and Chthamalus stellatus recruited to settlement panels in the Mediterranean coast of Israel. Isr J Zool 41:147-161

Southward AJ (1976) On the taxonomic status and distribution of Chthamalus stellatus (Cirripedia) in the north-east Atlantic region: with a key to the common intertidal barnacles of Britain. J Mar Biol Assoc UK 56:1007-1028 
Strathmann RR, Branscomb ES (1979) Adequacy of cues to favorable sites used by settling larvae of two intertidal barnacles. In: Stancyk SE (ed) Reproductive ecology of marine invertebrates. University of South Carolina Press, Columbia, p 77-89

Sutherland JP (1990) Recruitment regulates demographic variation in a tropical intertidal barnacle. Ecology 71 : 955-972

Underwood AJ (1981) Techniques of analysis of variance in experimental marine biology and ecology. Annu Rev Oceanogr Mar Biol 19:513-605

Underwood AJ, Denley EJ (1984) Paradigms, explanations and generalizations in models for the structure of inter-

Editorial responsibility: Otto Kinne (Editor),

Oldendorf/Luhe, Germany tidal communities on rocky shores. In: Strong DR, Simberloff D, Abele L, Thistle AB (eds) Ecological communities: conceptual issues and the evidence. Princeton University Press, Princeton, NJ, p 151-180

Wethey DS (1985) Local and regional variation in settlement and survival in the littoral Semibalanus balanoides (L.): patterns and consequences. In: Moore RS, Seed R (eds) The ecology of rocky coasts. Columbia University Press, New York, p 194-202

Winer BJ, Brown DR, Michelis KM (1971) Statistical principles in experimental design, 3rd edn. McGraw-Hill, New York Young BL (1991) Spartina axil zones: preferred settlement sites of barnacles. J Exp Mar Biol Ecol 151:71-82

Submitted: December 1, 1999; Accepted: November 19, 2002 Proofs received from author(s): February 18, 2003 